\title{
GROWTH PERFORMANCE OF GROWING LAMBS FED DIETS DIFFERING IN CONCENTRATE: ROUGHAGE RATIO AND SUPPLEMENTED WITH A PROBIOTIC
}

\author{
A.Z. Mehrez', A.A. Gabr ${ }^{1}$, M.Y. EL- Ayek ${ }^{1}$, M.R.M. Moustafa ${ }^{2}$ and E. \\ Kh. Hamed 1 \\ 1- Animal Production Department, Faculty of Agriculture, Mansoura University, \\ 2- Animal Production Research Institute, Ministry of Agriculture, Dokki
}

\section{SUMMARY}

Twenty four growing male Rahmani lambs $(26.8 \mathrm{~kg})$ were divided into 4 equal groups (6 lambs each), and were used to study the effect of feeding diets at two roughage (berseem hay, $B H$ ) : concentrate (concentrate feed mixture, CFM) ratios (66.6 : 33.4 and $33.4: 66.6 \%)$ i.e. high roughage (HR) and high CFM (HC) either with yeast culture (YCS) or without YC supplementation (UYC) $(0.25 \mathrm{~g} / 10 \mathrm{~kg}$ live body weight) on their productive performance and some blood constituents. The experimental period lasted for 180 days. Results obtained revealed that animal performance in terms of average daily gain, feed conversion efficiency and cost of feed/kg gain were higher with HC diets compared with HR ones. The YCS showed beneficial positive effect on tested animal performance parameters. Most of blood constituents were not significantly affected by $C: R$ ratio and YCS and their interaction .

Keywords: Yeast culture, roughage: concentrate ratio, sheep, blood constituents, animal performance

\section{INTRODUCTION}

Consistent literature has been published regarding the interest of the use of active dried yeast as a probiotic for ruminants (Dawson, 1994, Newbold et al., 1996, Abou Ward, 2001 El-Ashry et al.2001a\&b and Gabr et al., 2004) .

There is a widespread belief among dairy and beef producers and ruminant nutritionists that yeast products are beneficial by enhancing dry matter intake and overall animal performance. However, using yeast culture in ruminant diets recorded different responses, which may be referred to many different interactions among yeast sort, yeast level, diet and its composition, and also stage of livestock production. The ratio between roughage to concentrate $(R: C)$ represents one of the major dietary factors involved to influence the feed intake and utilization by ruminant animals $(\mathrm{Gabr}, 2000)$. The first part of present study has recently published by Gabr et al. (2004) and showed that yeast culture supplementation had positive effects on some rumen parameters ( $\mathrm{pH}$ values, VFA's and ammonia- $\mathrm{N}$ concentrations) , nutrients digestibility coefficients and feeding values (TDN and DCP\%) of tested 
diets with sheep, and had higher influence when included with high concentrate than high roughage - based diet.

The main objectives of this study were to investigate the effect of supplementing yeast culture to growing sheep diets at two roughage :concentrate ratios on some blood constituents and productive performance .

\section{MATERIALS AND METHODS}

The experimental work of this study was carried out at El-Serw Experimental Research Station, Animal Production Research Institute, Agriculture Research Center. Two diets containing two ratios $(33.4: 66.6)$ of roughage $\left(3^{\text {rd }}\right.$ cut berseem hay (Trifolium alexandrinum, L.) and concentrate ( concentrate feed mixture ,CFM) i.e. high roughage (HR) and high CFM (HC) without (UYC) or with yeast culture supplementation (YCS) were tested. The level of $0.25 \mathrm{~g} \mathrm{YC} \mathrm{(Lacture)} / \mathrm{d} / 10 \mathrm{~kg} \mathrm{BW}$ based on a recommended dose suggested by Gado et al. (1998) in rations of small ruminants was used. The tested diets were as follows: Diet 1: CFM, 66.6\%+33.4\% BH with YC (HC), Diet 2: CFM, 66.6\% + 33.4\% BH without YC(HC), Diet 3: CFM, 33.4\% + 66.6\% BH with YC (HR) and Diet 4: CFM, 33.4\% + 66.6\% BH without YC (HR). The chemical composition of the ingredients and the calculated composition of tested diets is previously published by Gabr et al. ( 2004) and presented in Table (1) . The concentrate feed mixture (CFM) contained 24\% undecorticated cotton seed meal, $20 \%$ yellow corn, $10 \%$ soybean meal, $14 \%$ rice bran, $25 \%$ wheat bran, $3 \%$ molasses, $2.5 \%$ limestone and $1.5 \%$ salt.

Twenty-four growing male Rahmani lambs, selected from El-Serw Station herd $(26.5 \pm 0.95 \mathrm{~kg})$ were randomly distributed according to their body weights into four equal groups, 6 lambs each. The animals of each group were kept in a separate shaded pen. The animals were fed for two weeks as a transitional period on the same experimental diets. Diets were offered at equal portions twice daily at 8.0 a.m and 3.0 p.m. Group feeding was applied and animals had no opportunity to eat other feeds. Offered amounts of roughage and concentrate were adjusted to keep (R:C) ratio to be closed to $(33.4: 66.6$ or $66.6: 33.4)$ every two weeks according to the change of live body weight. The amount of yeast culture was mixed with the mash portion of CFM prior feeding directly. Lambs were weighed at the beginning of the experiment and thereafter at two weeks intervals till the end of the experiment which lasted for 180 days. Feed intake was recorded and feed conversion was calculated. The nutrient requirements recommended by NRC (1985) for sheep were applied where it was adjusted every two weeks according to changes in body weight.

Table 1. Chemical analysis of the tested ingredients and formulated diets

\begin{tabular}{|c|c|c|c|c|c|c|c|c|}
\hline \multirow{2}{*}{ Item } & \multirow{2}{*}{ DM \% } & \multicolumn{7}{|c|}{ Chemical analysis (\% on DM basis) } \\
\hline & & $\mathbf{O M}$ & $\mathbf{C P}$ & CF & $\mathbf{E E}$ & NFE & Ash & GE \\
\hline Berseem hay $(\mathrm{BH})$ & 86.70 & 87.10 & 11.0 & 30.93 & 2.13 & 43.04 & 12.90 & 16.91 \\
\hline CFM & 91.00 & 91.00 & 15.55 & 16.86 & 3.3 & 55.56 & 9.00 & 17.82 \\
\hline \multicolumn{9}{|c|}{ Calculated chemical composition of tested diets, $\%$} \\
\hline $\mathrm{HC}$ diet & 89.63 & 89.33 & 13.61 & 22.87 & 2.65 & 50.21 & 10.67 & 17.43 \\
\hline HR diet & 88.17 & 88.09 & 12.11 & 27.37 & 2.36 & 46.21 & 11.91 & 17.13 \\
\hline
\end{tabular}

HC: high CFM $\mathrm{HR}$ : high BH 
Blood samples were taken during the last month of the feeding trial from the Jugular vein of growing lambs at $4 \mathrm{hrs}$ post-feeding into heparin - coated tubes and plasma was separated by centrifugation at 4000 r.p.m. for 10 minutes. The plasma samples were used for determination of total protein (Henry et al., 1974), albumin (A) (Doumas et al.,1971), globulin(G) (by calculation), A/G ratio (by calculation), urea (Fawcett and Scott, 1960), glucose (Teuscher and Richterich, 1971), cholesterol (Allain et al., 1974) and GOT and GPT (Reitman and Friankel, 1957) concentrations.

Data were analyzed using the general linear model procedure of SAS (1996). Differences among means were evaluated using Duncan's Multiple Range Test (1955).

\section{RESULTS AND DISCUSSION}

\section{Effects of R: C ratio and YCS on animal performance:}

The effects of $\mathrm{R}: \mathrm{C}$ ratio on animal performance are presented in Tables 2 and 3 . It was clear (Table 2) that animals fed HC diet had significantly $(\mathrm{P}<0.01)$ higher total body weight gain $(\mathrm{kg})$ than those fed HR diet, being 27.17 and $20.83 \mathrm{~kg}$, respectively. This could be related to the higher total DCP intake by G1 and G2 fed (HC) diet than those fed the HR ones (G3 and G4), being 146.72, $141.28,131.35$ and $125.9 \mathrm{~g} / \mathrm{d}$, respectively (Table 3$)$. Also, body weight gain ( $\mathrm{BWG})(\mathrm{g} / \mathrm{h} / \mathrm{d})$ for animals fed $\mathrm{HC}$ diets was significantly $(\mathrm{P}<0.05)$ higher than those fed on HR one, being 150.92 and $115.74 \mathrm{~g} / \mathrm{h} / \mathrm{d}$, respectively. The obtained results came in line with those recorded by Baik et al. (1997) and Hatfield et al. (1997) who found that increasing levels of concentrate improved the growth rate of sheep. Generally, it was clear from Table 2 that YCS had no significant effects on final live body weight ( FLBW) and BWG. However, the higher value $(140.28 \mathrm{~g} / \mathrm{h} / \mathrm{d})$ of BWG was recorded with YCS diet, while the lower value $(126.39 \mathrm{~g} / \mathrm{h} / \mathrm{d})$ was recorded with USYC diet. The obtained results are in agreement with those of Seymour et al. (1991); Drennan and Moloney (1993); Shetawei (1993) and Fayed (2001). They reported that no significant effect on BWG was detected by YCS.

Table 2. Mean effect of $\mathrm{R}: \mathrm{C}$ ratio and $\mathrm{YC}$ supplementation on changes in live body weight $(\mathrm{kg})$, average body weight gain and daily weight gain of the tested groups throughout the experimental period

\begin{tabular}{lcccccc}
\hline \multirow{2}{*}{ Weights } & \multicolumn{3}{c}{ C:R ratio } & \multicolumn{3}{c}{ YC supplementation } \\
\cline { 2 - 7 } & HC & HR & \pm SE & + & - & \pm SE \\
\hline Av. Initial LBW, Kg & 26.83 & 26.83 & 0.96 & 26.58 & 27.08 & 0.95 \\
Av. Final LBW, Kg & $54.00^{\mathrm{A}}$ & $47.67^{\mathrm{B}}$ & 1.36 & 51.83 & 49.83 & 1.87 \\
Total Gain (kg) & $27.17^{\mathrm{A}}$ & $20.83^{\mathrm{B}}$ & 1.34 & 25.25 & 22.75 & 1.82 \\
Average daily gain DG (g) & $150.92^{\mathrm{a}}$ & $115.74^{\mathrm{b}}$ & 7.43 & 140.28 & 126.39 & 10.13 \\
\hline
\end{tabular}

$\mathrm{a}, \mathrm{b} \& \mathrm{~A}$ and $\mathrm{B}$, means in the same row with different superscripts differ significantly $(\mathrm{P}<0.05) \&(\mathrm{P}<0.01)$.

Data in Table (3) indicate that interaction between $\mathrm{R}: \mathrm{C}$ ratio and $\mathrm{YC}$ supplementation were not significant on BWG. However, the higher values of final gain were recorded with groups treated with YC (G1 and G3), being 28.83 and 21.67 $\mathrm{kg}$, for $\mathrm{HC}$ and $\mathrm{HR}$, respectively, while the lower values were recorded with the 
USYC groups (G2 and G4) being 25.5 and $20 \mathrm{~kg}$, respectively. Also, daily gain $(\mathrm{g} / \mathrm{h} / \mathrm{d})$ took the same trend of total final gain.

The daily feed intake as DM/g/h/d was slightly higher for the two groups fed HC and those fed HR diets being lower for $\mathrm{HC}$ and higher for HR diets. Concerning, the feed conversion, the results in Table 3 reveal that the values were $8.38,9.49,12.56$ and $13.61 \mathrm{~kg} \mathrm{DM}$ intake/kg body gain for group 1, 2, 3 and 4, respectively. Also, feed conversion as expressed as ( $\mathrm{kg}$ TDN or DCP $/ \mathrm{kg}$ gain) was nearly similar for HC diets being lower relative to the HR diets As for the feeding cost $\mathrm{h} / \mathrm{d}$, the results in Table 3 show that there were no considerable differences among tested diets, however feed cost $/ \mathrm{kg}$ gain was lower for YCS with HC or HR diets. However, feed cost $/ \mathrm{kg} /$ gain was higher (on average) by about $27.7 \%$ for HR diets than that of $\mathrm{HC}$ ones.

Table 3. Effect of feeding tested diets on animal performance

\begin{tabular}{|c|c|c|c|c|c|}
\hline \multirow{3}{*}{ Item } & \multicolumn{4}{|c|}{ Tested diets } & \multirow{3}{*}{$\pm \mathbf{S E}$} \\
\hline & \multicolumn{2}{|c|}{$\mathrm{HC}$} & \multicolumn{2}{|c|}{ HR } & \\
\hline & $+\mathbf{G 1}$ & - G2 & $+\mathbf{G 3}$ & - G4 & \\
\hline No. of animals & 6 & 6 & 6 & 6 & \\
\hline Experimental & 180 & 180 & 180 & 180 & \\
\hline Av. Initial LBW, Kg & 26.50 & 27.17 & 26.67 & 27.00 & 1.98 \\
\hline Av. Final LBW, Kg & 55.33 & 52.67 & 48.33 & 47.00 & 2.61 \\
\hline Total BW gain, kg & 28.83 & 25.50 & 21.67 & 20.00 & 2.55 \\
\hline Av. Daily gain, $g$ & 160.18 & 141.67 & 120.37 & 111.11 & 14.17 \\
\hline $\begin{array}{l}\text { Daily feed intake, DM } \\
\mathrm{g} / \mathrm{h} / \mathrm{d}\end{array}$ & 1341 & 1350 & 1507 & 1512 & \\
\hline TDN intake $\mathrm{g} / \mathrm{h} / \mathrm{d}$ & 980.41 & 906.39 & 944.44 & 901.61 & \\
\hline Total CP intake $\mathrm{g} / \mathrm{h} / \mathrm{d}$ & 182.51 & 183.74 & 182.50 & 183.1 & \\
\hline DCP intake $\mathrm{g} / \mathrm{h} / \mathrm{d}$ & 146.72 & 141.28 & 131.35 & 125.9 & \\
\hline \multicolumn{6}{|l|}{ Feed conversion: } \\
\hline DM intake $\mathrm{kg} / \mathrm{kg}$ gain & 8.38 & 9.49 & 12.56 & 13.61 & \\
\hline $\mathrm{Kg}$ TDN/kg gain* & 6.12 & 6.40 & 7.84 & 8.11 & \\
\hline $\mathrm{Kg}$ DCP/ kg gain* & 0.916 & 0.997 & 1.091 & 1.133 & \\
\hline \multicolumn{6}{|l|}{ Economic efficiency : } \\
\hline Feed cost L.E./h/d & 0.71 & 0.70 & 0.69 & 0.69 & \\
\hline Feed cost L.E./kg gain & 4.41 & 4.94 & 5.77 & 6.17 & \\
\hline
\end{tabular}

HC: High concentrate feed mixture (CFM). HR: High roughage .

+ : with YC - : without YC

* TDN and DCP \% of tested diets were published by Gabr et al.(2004).

Effect of $R$ : C ratio and YCS on blood constituents :

The results of blood parameters of the tested groups as affected by $\mathrm{R}: \mathrm{C}$ ratio and YCS are presented in Table (4). The results indicate that GOT, GPT, cholesterol, total lipids, urea-N concentrations, albumin and $\mathrm{A} / \mathrm{G}$ ratio were not significantly 
affected by R:C ratio. Glucose and total protein were significantly $(\mathrm{P}<0.01)$ increased with increasing CFM in the diets by about $8.31 \%$ and $4.32 \%$ for $\mathrm{HC}$ and $\mathrm{HR}$ diet, respectively. Globulin was significantly $(\mathrm{P}<0.05)$ increased by about $8.68 \%$ by increasing CFM in the diet. Also, concentrations of GOT, GPT, glucose, cholesterol, total lipids, albumin and globulin and albumin (A) to globulin $(\mathrm{G})$ ratio (A/G ratio) were not significantly affected by YCS. These results are in accordance with those reported by El-Ashry et al. (2001a), Metwally et al. (2001) and Ibrahim et al. (2002). The YCS increased significantly $(\mathrm{P}<0.01)$ urea-N by about $21.58 \%$ relative to the unsupplemented diet. These findings are in accordance with those obtained by Giger-Reverdins et al. (1996); Gado et al. (1998), El-Ashry et al. (2001a\&b); Fayed (2001) and Ibrahim et al. (2002).

Table 4. Mean effect of R:C ratio and YC supplementation on some blood parameters

\begin{tabular}{lllllll}
\multirow{2}{*}{ Item } & \multicolumn{2}{l}{ C:R ratio } & \multicolumn{3}{c}{ YC supplementation } \\
\cline { 2 - 7 } & HC & HR & \pm SE & + & - & \pm SE \\
\hline GOT $(\mathrm{IU} / \mathrm{l})$ & 35.98 & 36.71 & 1.04 & 36.02 & 36.67 & 1.04 \\
GPT $(\mathrm{IU} / \mathrm{l})$ & 23.23 & 23.18 & 1.05 & 23.00 & 23.41 & 1.03 \\
Glucose $(\mathrm{mg} / 100 \mathrm{ml})$ & $72.711^{\mathrm{A}}$ & $67.13^{\mathrm{B}}$ & 1.71 & 71.19 & 68.65 & 2.30 \\
Cholesterol $(\mathrm{mg} / 100 \mathrm{ml})$ & 80.53 & 78.31 & 3.69 & 76.83 & 82.01 & 3.49 \\
Total lipids $(\mathrm{mg} / 100 \mathrm{ml})$ & 311.53 & 313.97 & 11.71 & 314.93 & 310.56 & 11.49 \\
Urea-N $(\mathrm{mg} / 100 \mathrm{ml})$ & 31.62 & 30.51 & 2.26 & $34.09^{\mathrm{A}}$ & $28.04^{\mathrm{B}}$ & 1.24 \\
Total protein g/100 ml & $7.49^{\mathrm{A}}$ & $7.18^{\mathrm{B}}$ & 0.12 & $7.46^{\mathrm{a}}$ & $7.21^{\mathrm{b}}$ & 0.13 \\
Albumin $(\mathrm{g} / 100 \mathrm{ml})$ & 3.86 & 3.86 & 0.07 & 3.89 & 3.83 & 0.06 \\
Globulin $(\mathrm{g} / 100 \mathrm{ml})$ & $3.63^{\mathrm{a}}$ & $3.34^{\mathrm{b}}$ & 0.11 & 3.57 & 3.40 & 0.14 \\
A/G ratio & 1.07 & 1.16 & 0.04 & 1.1 & 1.13 & 0.05
\end{tabular}

$\mathrm{a}, \mathrm{b}$ and A,B.. means in the same row with different superscripts differ significantly $(\mathrm{P}<0.05)$ \& $(\mathrm{P}<0.01)$.

Blood plasma total protein increased significantly $(\mathrm{P}<0.05)$ by using $\mathrm{YC}$ by about $3.47 \%$ compared with the unsupplemented diet. These results are in agreement with those reported by Abo El-Nor and Kholif (1998); El-Ashry et al. (2001a\&b); Fayed (2001) and Metwally et al. (2001).There was no significant effect for the interaction between $\mathrm{R}: \mathrm{C}$ ratio and YCS on all blood parameters for all tested groups.

It could be concluded that, yeast culture supplementation to growing sheep diets had positive effects on their productive performance without any adverse effect on blood constituents and has higher influence when included with high concentrate diet than high roughage- based diet.

\section{REFERENCES}

Abo El-Nor, S.A.H. and A.M. Kholif, 1998. Effect of supplementation of live yeast culture in the diet on the productive performance of lactating buffaloes. Milchwissenschaft, 53: 633 
Abou Ward, G.A., 2001. Supplementing finishing diets with yeast culture (Yea$\mathrm{SACC}^{1026}$ ) and its influence on lamb's performance. J. Agric. Sci. Mansoura Univ., 26: 2677.

Allain, C.C., L.S. Poon, C.S. Chan, W. Richmond and P.C. Fu, 1974. A method for determination of plasma cholesterol. Clin. Chemists. Official Methods of Analysis. $14^{\text {th }}$ Washington, D.C., USA.

Baik, M.G., J.K. Ha., W.Y. Kim and I.K. Han, 1997. Effects of different levels of concentrate in complete rations on nutrient digestibilities and ruminal metabolites in sheep and growth performance in Korean native bulls. Asian-Aust. J. Anim. Sci., 10:371.

Dawson, K.A., 1994. Current and future role of yeast culture in animal production. A review of research over the last six years. Proc. Alltech's $8^{\text {th }}$ Ann. Symp. (Suppl), Alltech, Tech. Publ., Kentucky USA, p 1.

Doumas, B.T., W. Watson and H.G. Biggs, 1971. A method of determination of plasma albumin. Clin. Chemists. Acta., 31: 87.

Drennan, M.J. and A.P. Moloney, 1993. Effect of yeast culture on growth of beef cattle fed on grass silage plus barley based concentrates. Irish J. Agricultural and Food Research, 32: 125.

Duncan, D.B., 1955. Multiple Range and Multiple F-Test. Biometrics, 11:10.

El-Ashry, M.A., A.M. Kholif, H.A. El-Alamy, H.M. El-Sayed and T.A. ElHamamsy, 2001a. Effect of different yeast cultures supplementation to diet on the productive performance of lactating buffaloes. Egyptian J. Nutrition and Feeds, 4: 21.

El-Ashry, M.A., Zeba A. Motagally and Y.A. Maareck, 2001b. Effect of live dried yeast and yeast culture on performance of growing buffalo calves.. Egyptian J. Nutrition and Feeds, 4 (Special Issue): 607.

Fawcett, J.K. and J.E.Scott, 1960. A method for determination of plasma urea. J. Clin. Path., 13: 156.

Fayed, Afaf M., 2001. Effect of using yea-sacc on performance of sheep and goats in Sinai. Egyptian J. Nutrition and Feeds, 4: 67.

Gabr, A.A., 2000. Assay of concentrate : roughage ratio for lactating farm animals. $5^{\text {th }}$ Vet. Med. Zag. Conf. (12-14 Sept. 2000), Sharm El-Sheikh, Egypt, 278-295.

Gabr, A.A, A.Z. Mehrez, M.Y. EL-Ayek , M.R. M . Moustafa and E. Kh Hamed, 2004. Influence of dry yeast culture (lacture) supplementation to sheep diets differing in roughage: concentrate ratio on nutrient digestibilities, feeding values and some rumen parameters . ${ }^{\text {th }}$ Vet. Med. Zag. Conference( 21-23 July) Sharm El- Sheikh, Egypt,117-129.

Gado, H.M., A.Y. Badawi, F.L.S. Helal and Sohair A.Nasr, 1998. Effect of yeast culture supplementation level on the growth performance of growing goats. Arab Univ. J. Agric. Sci., Ain Shams Univ., Cairo, 6: 123.

Giger-Reverdins, S., N. Bezault, D. Sauvant and G. Bertin, 1996. Effects of probiotic yeast in lactating ruminants: Interaction with dietary nitrogen level. Animal Feed Sci. Tech., 63:149

Hatfield, P.G., J.A. Hopkins, G.T. Pritchard and C.W. Hunt, 1997. The effect of amount of whole barley bulk density and form of forage on feedlot lamb performance, carcass characteristics and digesta kinetics. J. Anim. Sci., 75:3353. 
Henry, R.J., C.D. Cannon and J.W. Winkelman, 1974. A method of determination of plasma total protein. Clin. Chem. Principles and Techniques. Harper and Row, Publ. pp 415.

Ibrahim, Fathia A., M.E. Ahmed, Ahlam A. El-Shewy and Faten F. Abou Ammou, 2002. Effect of commercial microbial supplements on performance of lactating Zaraibi goats. Proc. $1^{\text {st }}$ Ann. Sc. Conf. Anim. and Fish Prod., Mansoura $24 \& 25$ Sep., 2002.

Metwally, A.M., I.S. El-Shamaa and M. Abd El-Momin, 2001. Changes in some blood constituents, growth rate and rumen fermentation of growing lambs fed yeast culture. Second International Conference on Animal Production and Health in Semi-Arid Areas. Irish, 131.

Newbold, C.J, R.J. Wallace and F.M. Mc Intosh, 1996. Mode of action of the yeast Saccharomyes cerevisiae as feed additive for ruminants. British J. of Nutrition, 76: 249.

NRC, National Research Council, 1985. Nutrient Requirements of Sheep. $6^{\text {th }}$ Revised Ed. Nat. Acad. Press., Washington, D.C.

Reitman, S. and S. Frankel, 1957. A method for determination of plasma GOT and GPT. Am. J. Clin. Path., 28: 56.

SAS, 1996. SAS User's Guide. Statistical Analysis System. Instit., Inc., Cary, NC, USA.

Seymour, W., J. Siciliono-Janes and J.E. Nocek, 1991. Effects of feeding Saccharomyes cerevisiae as live yeast culture on milk and dry matter intake in high producing cows. J. Dairy Sci., 74 (supplement 1): 176.

Shetawi, M.M., 1993. Responses of feed lot lambs to live yeast culture supplementation. Assuit Vet. Med. J., 28:108.

Teuscher, A. and R. Richterich, 1971. Schweidz. Med-Woschr, 101: 345. 


\section{الأداء الإنتاجى للحملان النامية المغذاة على علائق مختلفة فى نسبة المواد المركزة الى الخثنة \\ والمضاف اليها مركبات البرويايوتك \\ أحمد زكى محرز ' , أحمد عبد الرازق جبر' ، محمود يوسف العايق '، محمد رفاعى محمود مصطفى' ،

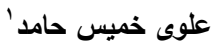

1 - قسم الإنتاج الحيواني، كلية الزراعة، جامعة الدنصورةمصر، r- معطُ بحوث الإنتاج الحيوانى، وزارة



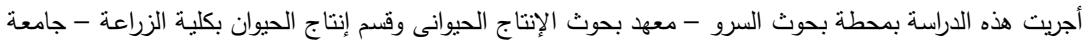

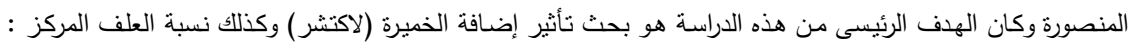



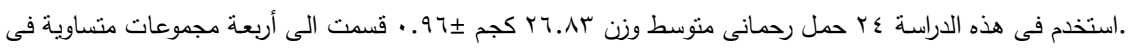

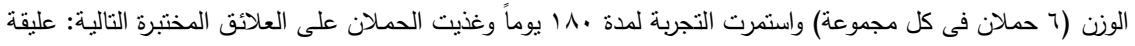

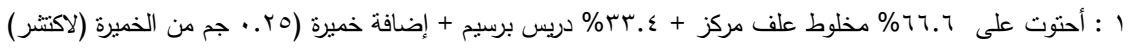



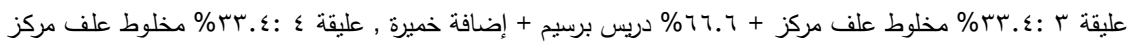



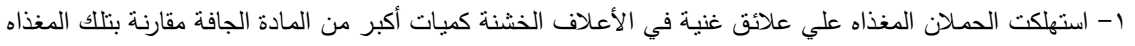

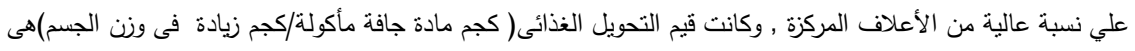

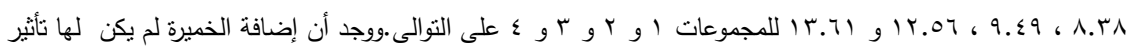

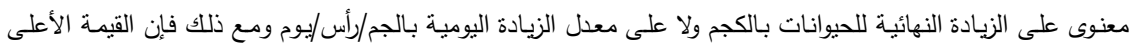

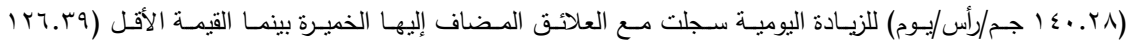

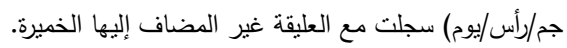

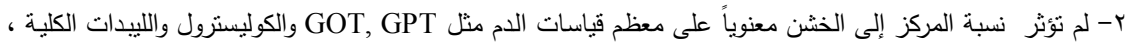

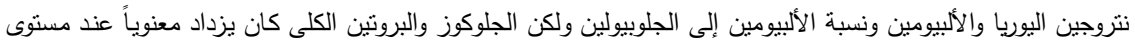

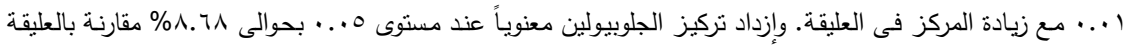

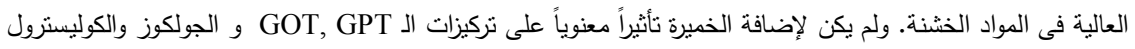



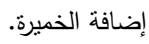

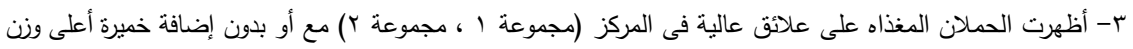

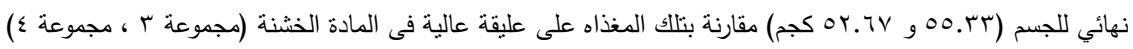

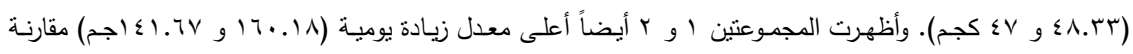



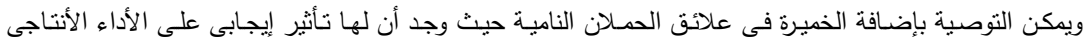

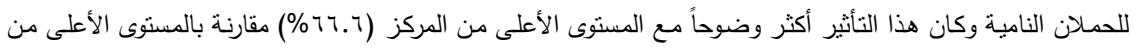

